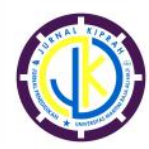

\title{
ANALISIS EFEKTIVITAS MODEL PEMBELAJARAN ARIAS BERBANTUAN LKS DALAM MENINGKATKAN KEMAMPUAN PEMECAHAN MASALAH MATEMATIS SISWA
}

\author{
Rini Elyani ${ }^{1 *}$, Nur Izzati $^{2}$, Sukma Adi Perdana ${ }^{3}$ \\ 1,2Universitas Maritim Raja Ali Haji, Tanjungpinang, Kepulauan Riau 29111, Indonesia \\ ${ }^{3}$ Sekolah Tinggi Agama Islam Negeri Sultan Abdurrahman, Kepulauan Riau 29111, Indonesia
}

Pengiriman: 13 Juni 2019; Diterima: 7 Juli 2019; Publikasi: 28 Juli 2019

\begin{abstract}
Abstrak
Rendahnya daya serap siswa dikarenakan sistem pembelajaran yang masih konvensional di mana pada pembelajaran konvensional guru memberikan informasi dan siswa hanya sebagai seorang penerima dari informasi tersebut.Begitu juga dalam pemecahan masalah saat pembelajaran matematika berlangsung, siswa tidak pernah mencoba cara atau strategi lain dalam memecahkan masalah. Salah satu upaya yang dilakukan untuk mengatasi permasalahan tersebut adalah penerapan model pembelajaran ARIAS (Assurance, Relevance, Interest, Assessment, Satisfaction) dengan berbantuan Lembar Kegiatan Siswa (LKS). Maka peneliti akan melakukan penelitian mengenai keefektifan penggunaan model pembelajaran ARIAS berbantuan Lembar Kegiatan Siswa (LKS) dengan tujuan penelitian untuk mengetahui dan mendeskripsikan proses pelaksanaan pembelajaran matematika dengan menerapkan model pembelajaran ARIAS pada pokok bahasan himpunan. Penelitian ini merupakan penelitian kualitatif siswa kelas VII SMP Negeri 7 Tanjugpinang. Penelitian ini merupakan penelitian kualitatif dengan teknik observasi. Dalam penelitian ini digunakan teknik observasi yaitu berupa pengamatan yang dilakukan oleh observer terhadap peneliti dan siswa pada saat proses pembelajaran berlangsung. Pengamatan tersebut dilakukan dengan menggunakan lembar observasi kegiatan guru dan lembar observasi kegiatan siswa. Serta digunakan lembar tes untuk melihat keefektifan model pembelajaran ARIAS terhadap kemampuan pemecahan masalah matematis dalam pembelajaran matematika. Berdasarkan penilaian yang didapat pada saat pengamatan, dapat disimpulkan bahwa pelaksanaan pembelajaran berjalan sesuai dengan langkah-langkah dari model pembelajaran ARIAS. Berdasarkan hasil dan pembahasan maka penerapan model pembelajaran dikatakan efektif dalam meningkatkan kemampuan pemecahan masalah.
\end{abstract}

Kata kunci:model pembelaran ARIAS; kemampuan pemecahan masalah

\begin{abstract}
The low absorptive capacity of students is due to the conventional learning system in which in conventional learning the teacher provides information and students only as a recipient of that information without seeking prior information to study at school. Likewise in solving problems when learning mathematics takes place, students never try other ways or strategies in solving problems. One of the
\end{abstract}

*Penulis Korespondensi

Email Address: elyanirini@gmail.com 
efforts made to overcome these problems is the application of the ARIAS learning model (Assurance, Relevance, Interest, Assessment, Satisfaction) with the help of Student Activity Sheets (LKS). then the researcher will conduct research on the effectiveness of using the Assisted Student Activity (LKS) ARIAS learning model with the aim of research to find out and describe the process of implementing mathematics learning by applying the ARIAS learning model on the subject matter of the set. This research is a qualitative study of class VII students of SMP Negeri 7 Tanjugpinang. This research is a qualitative research with observation techniques. In this study, observation techniques were used, in the form of observations made by observers on researchers and students during the learning process. The observations were carried out using observation sheets of teacher activities and observation sheets of student activities. The test sheet was also used to see the effectiveness of the ARIAS learning model for mathematical problem solving abilities in mathematics learning. Based on the assessment obtained at the time of observation it can be concluded that the implementation of learning goes according to the steps of the ARIAS learning model. Based on the results and discussion, the application of the learning model is said to be effective in improving problem solving skills.

Keywords ARIAS learning model;problem solving ability:

\section{PENDAhuluan}

Berdasarkan penelitianpendahuluan yang dilakukan pada semester ganjil Tahun Pelajaran 2018/2019 di SMP Negeri 7 Tanjungpinang Timur, diketahui bahwa aktivitas-aktivitas kognitif siswa kelas VII dalam kegiatan pembelajaran matematika belum optimal. Aktivitas-aktivitas kognitif siswa yang belum optimal tersebut yaitu mengingat, menyimbolkan, mengkategorikan, berpikir dan memecahkan masalah. Dalam aktivitas mengingat, diketahui bahwa siswa sering lupa materi yang telah dipelajari sebelumnya. Sehingga ketika guru melakukan apersepsi dengan menanyakan kembali materi yang telah dipelajari, siswa tidak bisa menjawab pertanyaan guru tersebut.

Dalam aktivitas menyimbolkan, menyimbolkan disini terkhusus untuk pelajaran Himpunankarena diketahui bahwa siswa masih sukar dalam menggunakan simbol-simbol dalam matematika. Masih banyak siswa yang kurang memahami mengenai simbol-simbol matematika pada materi Himpunan, khususnya dalam penyelesaian soal cerita. Siswa masih mengalami kesulitan membahasakan soal ke dalam simbol matematika. Kemudian dalam aktivitas mengkategorikan, diketahui bahwa siswa sering mencampur adukkan materi yang satu dengan lainnya.

Berdasarkan fakta empiris, diketahui bahwa siswa belum terbiasa berpikir kritis. Siswa masih terbiasa meniru apa yang dicontohkan oleh guru, tanpa mau berpikir mencari alternatif jawaban lain yang lebih mudah dimengerti. Dengan kata lain kemampuan berpikir siswa hanya terbatas pada hal-hal rutin. Dalam aktivitas memecahkan masalah, diketahui bahwa siswa belum optimal dalam menyelesaikan soal pemecahan masalah. Siswa cendrung langsung mengerjakan soal untuk mencari jawaban tanpa mencoba melakukan kegiatan memahami soal, merencanakan penyelesaian, menyelesaikan masalah sesuai rencana dan melakukan pengecekan kembali terhadap semua langkah yang telah dikerjakan. Sehingga sering terdengar bahwa siswa lebih suka ujian objektif daripada essay karena tidak dituntut membuat proses penyelesaian soal. Fakta empiris ini, sesuai dengan hasil penelitian yang dilakukan oleh Yudiana (2015) yang menunjukkan bahwa siswa masih lemah dalam hal kemampuan berpikir kritis.

Di antara faktor penyebab belum optimalnya aktivitas kognitif siswa dalam pembelajaran matematika di antaranya adalah adanya kecenderungan siswa diarahkan untuk menghapal segala informasi yang nantinya informasi tersebut digunakan oleh siswa dalam menyelesaikan suatu masalah yang berkaitan dengan matematika. Hal ini menyebabkan rendahnya kemampuan siswa dalam memahami kemampuan matematis.

Saat ini Kurikulum 2013 sudah diberlakukan di tingkat SD, SMP, dan SMA. Namun kerap terjadi perbedaan antara teori dan implementasi dari kurikulum tersebut dimana 
pembelajaran masih banyak yang dilakukan dengan konvensional. Pada pembelajaran konvensional ini guru memberikan informasi dan siswa hanya sebagai seorang penerima dari informasi tersebut tanpa mencari informasi terdahulu sebelum belajar di sekolah. Begitu juga dalam pemecahan masalah saat pembelajaran matematika berlangsung, siswa tidak pernah mencoba cara atau strategi lain dalam memecahkan masalah.

Sementara dalam lampiran

Permendikbud Nomor 58 Tahun 2014 tentang

Kurikulum SMP dijelaskan bahwa mata pelajaran matematika bertujuan agar peserta didik mendapatkan beberapa hal, salah satu diantaranya adalah memiliki sikap menghargai kegunaan dari pembelajaran matematika dalam kehidupan, yaitu memiliki rasa ingin tahu, perhatian, dan minat dalam mempelajari matematika, serta sikap ulet dan percaya diri dalam pemecahan masalah.

Upaya yang dilakukan untuk mengatasi permasalahan di atas adalah menerapkan salah satu pendekatan pembelajaran yang mampu membangun berpikirnya seorang siswa dengan mengasah kemampuan berpikir kritis dalam memecahkan masalah maka dengan begitu kemampuan pemecahan masalah siswa akan meningkat dan juga akan berdampak pada peningkatan hasil belajar siswa. Salah satu cara yang dapat dilakukan adalah menggunakan model pembelajaran ARIAS (Assurance, Relevance, Interest, Assessment, Satisfaction). Model pembelajaran ARIAS terdiri dari lima komponen (Assurance, Relevance, Interest, Assessment, Satisfaction). Dimana proses pembelajaran dengan menggunakan model pembelajaran ARIAS dimulai dari tahap Assurance agar siswa memiliki rasa percaya diri terhadap kemampuan yang dimilikinya. Dilanjutkan tahap Relevance, pembelajaran diarahkan pada hal-hal yang relevan dengan kehidupan siswa. Kemudian tahap Interest, games dan diskusi kelompok digunakan untuk menarik minat dan perhatian siswa. Dilanjutkan tahap Assessment untuk mengetahui kemampuan siswa. Kemudian yang terakhir adalah tahap Satisfaction, hal ini berhubungan dengan rasa bangga, puas atas hasil yang dicapai.

Beberapa penelitian terdahulu menunjukkan keberhasilan penerapa model Pembelajaran ARIAS ini dalam meningkatkan hasil belajar. Misalnya penelitian yang dilakukan oleh Sesilawati (2016) yang menunjukkan adanya peningkatan hasil belajar dan minat belajar siswa dengan menerapkan model pembelajaran ARIAS. Selanjutnya, penelitian yang dilakukan Hidayati (2018) juga memberikan hasil yang serupa dengan hasil penelitian Sesilawati (2016), di mana terjadi peningkatan hasil belajar siswa pada pelajaran IPS materi ekonomi masyarakat Indonesia setelah belajar menggunakan model pembelajaran ARIAS. Begitu pula halnya dengan penelitian yang dilakukan Anjariyah dan Karlina (2016) yang menunjukkan terjadinya peningkatan minat belajar matematika siswa yang belajar menggunakan model pembelajaran ARIAS.

Model pembelajaran ARIAS merupakan modifikasi dari model pembelajaran Attention, Relevance, Confidence, dan Satisfaction (ARCS) yang dikembangkan oleh John M. Keller dengan menambahkan komponen assessment pada keempat komponen model pembelajaran tersebut. Model pembelajaran ARCS ini dikenal secara luas sebagai Keller's ARCS Model of Motivation. Model ini dikembangkan dalam wadah Center for Teaching, Learning \& Faculty Development di Florida State University (Keller, dalam Ivana, 2016:14).

Model pembelajaran ini dikembangkan sebagai jawaban pertanyaan bagaimana merancang pembelajaran yang dapat mempengaruhi motivasi berprestasi dan hasil belajar. Model pembelajaran ini dikembangkan berdasarkan teori nilai harapan (expectancy value theory) yang mengandung dua komponen yaitu nilai (value) dari tujuan yang akan dicapai dan harapan (expectancy) agar berhasil mencapai tujuan itu. Dari dua komponen tersebut oleh 
Keller dikembangkan menjadi empat komponen. Keempat komponen model pembelajaran itu adalah Attention, Relevance, Confidence, dan Satisfaction (ARCS) (Keller \& Suzuki dalam Ivana, 2016:5) menyatakan bahwa, dari keempat bagian tersebut dikembangkan menjadi beberapa langkah. Namun demikian, pada model pembelajaran ini belum ada bagian assessment, padahal assessment merupakan komponen yang tidak dapat dipisahkan dalam kegiatan pembelajaran.Assessment yang dilaksanakan tidak hanya pada akhir kegiatan pembelajaran tetapi perlu dilaksanakan selama proses kegiatan berlangsung. Assessment dilaksanakan untuk mengetahui sampai sejauh mana kemajuan yang dicapai atau hasil belajar yang diperoleh siswa.Assessment yang dilaksanakan selama proses pembelajaran dapat mempengaruhi hasil belajar siswa. Mengingat pentingnya assessment, maka model pembelajaran ini dimodifikasi dengan menambahkan komponen assessment pada model pembelajaran tersebut. Dengan modifikasi tersebut, model pembelajaran yang digunakan mengandung lima komponen yaitu: attention (minat); relevance (relevansi); confidence (percaya); satisfaction (kepuasan), dan assessment (evaluasi). Modifikasi juga dilakukan dengan penggantian namaconfidence menjadi assurance, dan attention menjadi interest. Penggantian namaconfidence (percaya diri) menjadi assurance, karena kata assurance sinonim dengan kata self-confidence.

Hal ini dimaksudkan agar dalam kegiatan pembelajaran guru tidak hanya percaya bahwa siswa akan mampu dan berhasil, melainkan juga sangat penting menanamkan rasa percaya diri siswa bahwa mereka merasa mampu dan dapat berhasil. Penggantian juga dilakukan pada kata attention menjadi interest, karena pada kata interest (minat) sudah terkandung pengertian attention (perhatian). Dengan kata lain interest tidak hanya sekedar menarik minat siswa pada awal kegiatan melainkan tetap memelihara minat tersebut selama kegiatan pembelajaran berlangsung. Untuk memperoleh akronim yang lebih baik dan lebih bermakna maka urutannyapun dimodifikasi menjadi assurance, relevance, interest, assessment dan satisfaction (ARIAS) (Sopah dalam Ivana, 2016:16).

Dengan mengambil huruf awal dari masing-masing komponen menghasilkan kata ARIAS sebagai akronim. Oleh karena itu, model pembelajaran yang sudah dimodifikasi ini disebut model pembelajaran ARIAS. Jadi, model pembelajaran ARIAS adalah suatu model pembelajaran yang menanamkan rasa yakin atau percaya diri pada siswa, memiliki relevansi dengan kehidupan siswa, mampu menarik dan memelihara minat/perhatian siswa, mengadakan evaluasi terhadap pembelajaran dan menumbuhkan rasa puas pada diri siswa.

Berdasarkan kelima komponen tersebut, berikut langkah-langkah dari model pembelajaran ARIAS (dalam Supriyanti, 2015:44). Akan disajikan pada Tabel berikut:

Tabel 1. Langkah-Langkah Pembelajaran ARIAS

\begin{tabular}{|c|l|}
\hline Tahap & \multicolumn{1}{|c|}{ Perilaku Guru } \\
Tahap 1 & $\begin{array}{l}\text { Guru menanamkan pada siswa } \\
\text { gambaran diri positif terhadap } \\
\text { diri sendiri dan membantu } \\
\text { siswa menyadari kekuatan dan } \\
\text { kelemahan diri (menumbuhkan } \\
\text { rasa percaya diri). }\end{array}$ \\
\hline & $\begin{array}{l}\text { Guru memberikan informasi } \\
\text { kompetensi yang akan dicapai } \\
\text { dan mengemukakan tujuan atau } \\
\text { manfaat pelajaran bagi } \\
\text { kehidupan dan aktivitas siswa } \\
\text { baik untuk masa sekarang } \\
\text { maupun mendatang. }\end{array}$ \\
Relevance \\
Tahap 3 & $\begin{array}{l}\text { Guru memberi kesempatan } \\
\text { siswa untuk berpartisipasi } \\
\text { secara aktif dalam pembelajaran } \\
\text { dan mengadakan variasi dalam } \\
\text { pembelajaran. }\end{array}$ \\
\hline Tahap 4 & $\begin{array}{l}\text { Guru mengukur pemahaman } \\
\text { peserta didik melalui beberapa } \\
\text { pertanyaan tertulis. }\end{array}$ \\
Assessment \\
\hline Tahap 5 & $\begin{array}{l}\text { Guru memberikan pujian } \\
\text { kepada siswa yang mendapat } \\
\text { nilai tertinggi. }\end{array}$ \\
\hline
\end{tabular}

Dilihat dari komponen-komponennya, model ini diharapkan dapat meningkatkan kemampuan pemecahan masalah matematis 
siswa. Karena model pembelajaran ini akan memberikan arahan bagaimana cara siswa menyelesaikan suatu masalah. Tidak hanya model pembelajaran yang berpengaruh dalam proses pembelajaran, proses pembelajaran akan lebih baik juga jika ditambah dengan berbantuan penggunaan LKS yang dirancang sebagai salah satu cara mengajar yang tepat dilakukan oleh guru untuk menumbuhkan kemampuan pemecahan masalah matematis dalam proses pembelajarannya, model pembelajaran ARIAS ini dapat digunakan oleh para guru sebagai dasar melaksanakan kegiatan pembelajaran dengan baik, dan sebagai suatu alternatif dalam usaha meningkatkan kemampuan pemecahan masalah matematis siswa.

Oleh karena itu, peneliti berkeinginan meneliti dengan rumusan masalahnya adalah "bagaimanakah efektivitas model pembelajaran ARIAS berbantuan LKS terhadap kemampuan pemecahan masalah?. Selanjutnya, tujuan dari penelitian ini adalah untuk mengetahui dan mendeskripsikan efektivitas model pembelajaran ARIAS berbantuan LKS terhadap kemampuan pemecahan masalah.

\section{METODE PENELITIAN}

Jenis penelitian ini merupakan deskriptif kualitatif dengan subjek penelitian adalah adalah siswa kelas VII SMP Negeri 7 Tanjungpinang Sampel dalam penelitian ini diambil dengan cara acak kelas, yaitu dengan cara mengundi masingmasing nomor kelas VII yang terdiri dari 11 kelas. Hasil dari undian dipilih 2 kelas sebagai kelas kontrol dan kelas eksperimen. Berdasarkan hasil undian yang dilakukan oleh peneliti maka yang menjadi kelas eksperimen yaitu kelas VII 2 dengan jumlah siswa sebanyak 40 orang dan yang menjadi kelas kontrol yaitu kelas VII 3 dengan jumlah siswa sebanyak 40 orang.Penelitian ini dilakukan pada semester ganjil tahun pelajaran 2018/2019. Teknik pengumpulan data dalam penelitian ini menggunakan metode observasi dan metode tes.

Teknik analisis data yang digunakan pada peneliti ini mengacu pada teknik analisis datayang dikemukakan oleh Miles and Huberman (1984). Teknik ini dilakukan secara interaktif, terus menerus dan lebih difokuskan selama proses di lapangan bersamaan dengan pengumpulkan data (Sugiyono,2018:249). Menurut Miles and Huberman, kegiatan analisis terdiri dari tiga alur kegiatan yang terjadi secara bersamaan, yaitu reduksi data, penyajian data, dan penarikan kesimpulan/verifikasi. Terjadi secara bersamaan berarti reduksi data, penyajian data, dan penarikan kesimpulan/verivikasi sebagai sesuatu yang saling jalin menjalin merupakan proses siklus dan interaksi pada saat sebelum, selama, dan sesudah pengumpulan data dalam bentuk sejajar yang membangun wawasan umum yang disebut "analisis" (Ulber Silalahi dalam Ega, 2013:38).

Observasi ini dilakukan peneliti melalui partisipasi dalam kegiatan pembelajaran di dalam kelas.Peneliti mengikuti kegiatan pembelajaran pada materi himpunan. Dalam hal ini peneliti akan menggunakan instrumen berupa lembar observasi guru dan siswa. Lembar observasi terhadap guru yaitu tentang bagaimana kemampuan guru mengelola pembelajaran ARIAS, sedangkan lembar observasi terhadap siswa yaitu tentang bagaimana aktivitas siswa selama proses pembelajaran berlangsung. Sebelum digunakan instrument telah divalidasi dan hasil validasinya valid. Dengan mengamati suasana pembelajaran yang ada di dalam kelas tersebut didapat data yang diinginkan. Data tersebut digunakan sebagai salah satu acuan untuk menentukan efektivitas model pembelajaran ARIAS.

Lembar observasi ini terlebih dahulu di validasi agar mengetahui apakah lembar observasi ini bisa digunakan sebagai alat ukur dalam penelitian. Dimana lembar validasi lembar observasi ini mempunyai 4 aspek : format, isi, bahasa dan tulisan, serta manfaat lembar observasi. Masing-masing aspek memiliki rentang penilaian $(1,2,3,4,5)$ sebagaimana diungkapkan oleh Riduwan (2011:15) kriteria interpretasi kelayakan instrumen lembar observasi diantaranya sebagai berikut: 
JURNAL KIPRAH, Juli 2018; VII(1): 49-58

e-ISSN: 2580-6947

p-ISSN: 2354-7278

Tabel 2. Kriteria Interpretasi Kelayakan

Instrumen Lembar Observasi

\begin{tabular}{|c|l|l|}
\hline No & \multicolumn{1}{|c|}{ Penilaian } & \multicolumn{1}{c|}{ Kategori } \\
\hline 1 & $0 \%-20 \%$ & Sangat Kurang Baik \\
\hline 2 & $21 \%-40 \%$ & Kurang Baik \\
\hline 3 & $41 \%-60 \%$ & Cukup Baik \\
\hline 4 & $61 \%-80 \%$ & Baik \\
\hline 5 & $81 \%-100 \%$ & Sangat Baik \\
\hline
\end{tabular}

Tabel 3 dan Tabel 4 menyajikan hasil analisis lembar observasi aktivitas guru dan lembar observasi aktivitas siswa.

Tabel 3.Analisis Lembar Validasi Lembar Observasi Aktivitas Guru

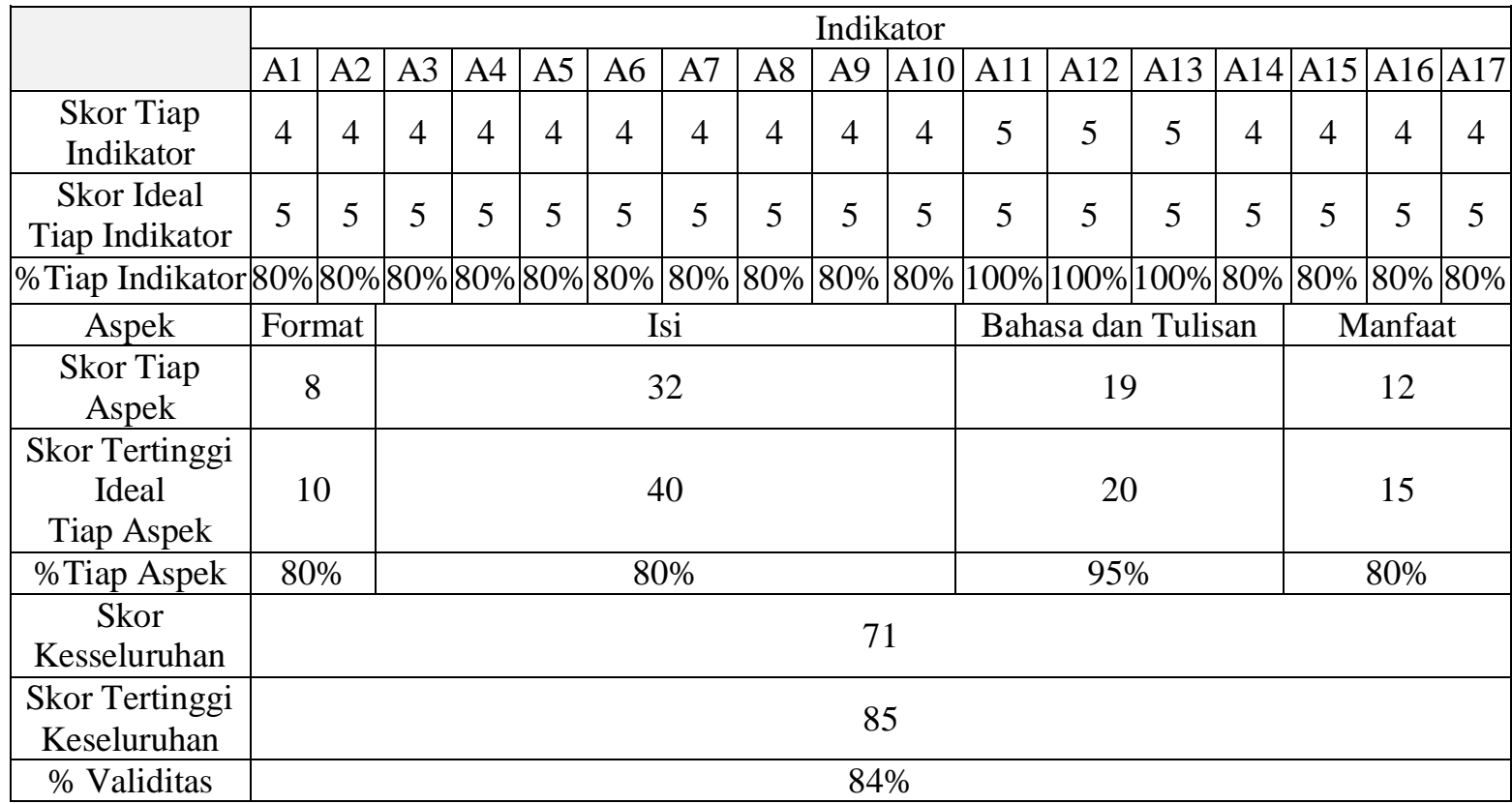

Tabel 4.Analisis Lembar Validasi Lembar Observasi Aktivitas Siswa

\begin{tabular}{|c|c|c|c|c|c|c|c|c|c|c|c|c|c|c|c|c|c|}
\hline & & & & & \multicolumn{13}{|c|}{ Indikator } \\
\hline & A1 & A2 & A3 & A4 & A5 & A6 & A7 & A8 & A9 & A10 & A11 & A12 & A13 & A14 & A15 & A16 & A17 \\
\hline $\begin{array}{l}\text { Skor Tiap } \\
\text { Indikator }\end{array}$ & 4 & 4 & 4 & 4 & 4 & 4 & 4 & 4 & 4 & 4 & 5 & 5 & 5 & 4 & 4 & 4 & 4 \\
\hline $\begin{array}{c}\text { Skor } \\
\text { Tertinggi } \\
\text { Ideal } \\
\text { Tiap Indikator } \\
\end{array}$ & 5 & 5 & 5 & 5 & 5 & 5 & 5 & 5 & 5 & 5 & 5 & 5 & 5 & 5 & 5 & 5 & 5 \\
\hline $\begin{array}{l}\text { \%Tiap } \\
\text { Indikator }\end{array}$ & $80 \%$ & $80 \%$ & $80 \%$ & $80 \%$ & $80 \%$ & $80 \%$ & $80 \%$ & $80 \%$ & $80 \%$ & $80 \%$ & $\begin{array}{c}100 \\
\%\end{array}$ & $\begin{array}{c}100 \\
\%\end{array}$ & $\begin{array}{c}100 \\
\%\end{array}$ & $80 \%$ & $80 \%$ & $80 \%$ & $80 \%$ \\
\hline Aspek & For & mat & & & & & Isi & & & & $\mathrm{Bah}$ & asa da & an Tul & lisan & & Manfac & \\
\hline $\begin{array}{l}\text { Skor Tiap } \\
\text { Aspek }\end{array}$ & & 8 & & & & & 32 & & & & & 1 & 9 & & & 12 & \\
\hline $\begin{array}{c}\text { Skor } \\
\text { Tertinggi } \\
\text { Ideal } \\
\text { Tiap Aspek }\end{array}$ & & 0 & & & & & 40 & & & & & 2 & & & & 15 & \\
\hline \% Tiap Aspek & 80 & $\%$ & & & & & $80 \%$ & & & & & 95 & & & & $80 \%$ & \\
\hline $\begin{array}{c}\text { Skor } \\
\text { Kesseluruhan }\end{array}$ & & & & & & & & & 71 & & & & & & & & \\
\hline $\begin{array}{c}\text { Skor } \\
\text { Tertinggi } \\
\text { Keseluruhan }\end{array}$ & & & & & & & & & 85 & & & & & & & & \\
\hline
\end{tabular}




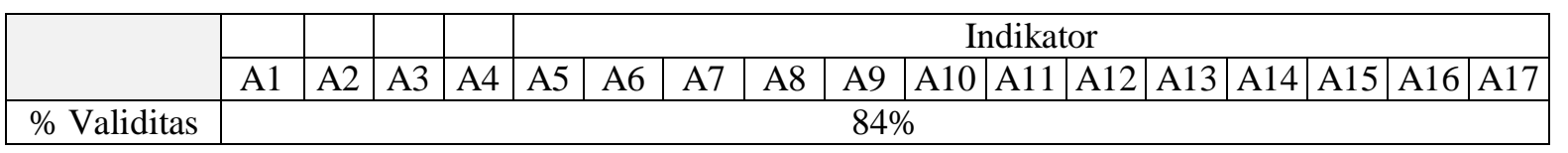

Berdasarkan analisis lembar aktivitas guru dan lembar validasi aktivitas siswa, dapat disimpulkan bahwa, lembar observasi guru dan lembar observasi siswa berkategori sangat baik. Di mana lembar observasi guru dan lembar observasi siswa memiliki persentase yang sama yaitu $84 \%$ yang berarti masuk ke dalam kategori sangat baik dan layak untuk digunakan pada penelitian.

Selanjutnya metode Tes, metode ini digunakan untuk mendapatkan data atau hasil yang digunakan sebagai bahan untuk mengukur sejauh mana siswa dapat menyerap materi himpunan melalui tes tertulis yang dilakukan. Nilai tes dari masing-masing siswa akan digunakan sebagai salah satu acuan dalam menentukan efektivitas model pembelajaran ARIAS. Dengan melihat persentase ketuntasan belajar, baik secara klasikal maupun individual.Kriteria dinyatakan tuntas belajar berdasarkan KKM yang ditetapkan disekolah yaitu $\geq 70$. Satu kelas dinyatakan tuntas belajar jika siswa dikelas tersebut mencapai daya serap sekurang-kurangnya $80 \%$.Berikut adalah kriteria ketuntasan beserta rumusnya (Qadriyah dalam Sinyo, 2015:352).

Keterangan:

$$
\mathrm{KB}=\frac{\mathrm{Ni}}{N} \times 100 \%
$$

KB : Ketuntasan belajar klasikal

$\mathrm{N}$ : Banyak siswa yang memperoleh skor $\geq 70$

$\mathrm{N}$ : banyak siswa yang mengikuti tes

Jika ketuntasan belajar siswa $\geq 70$ maka dapat dikatakan bahwa model pembelajaran ARIAS efektif dalam proses pembelajaran untuk mengukur kemampuan pemecahan masalah matematis siswa.

\section{HASIL DAN PEMBAHASAN}

Pelaksanaan pembelajaran dengan model pembelajaran ARIAS pada kelas VII 2 sebanyak 4 pertemuan dengan materi bentuk himpunan.
Pada tahap awal proses pembelajaran guru menyiapkan kondisi fisik siswa, setelah itu guru mengajak siswa untuk mengaitkan materi yang akan diajarkan dengan materi sebelumnya. Selanjutnya masuk ke tahap Relevance, yaitu guru mengemukakan tujuan atau manfaat materi yang akan diajarkan yaitu materi himpunan bagi kehidupan dan aktivitas siswa. Selanjutnya masuk ke tahap Assurance, yaitu guru menanmkan rasa percaya diri siswa dengan cara guru memberikan pertanyaan yang menantang sehingga membuat siswa termotivasi untuk menjawab pertanyaan tersebut. Berdasarkan pada Gambar 1 berikut ini terlihat siswa termotivasi untuk mengikuti pelajaran.

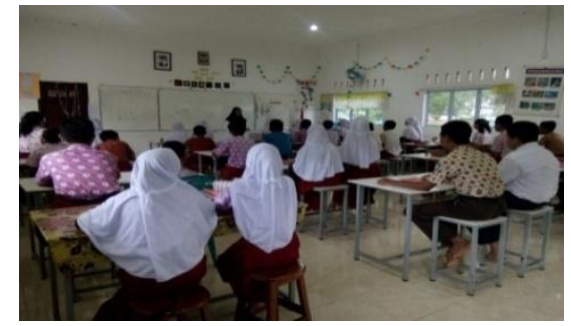

Gambar 1. Memotivasi Siswa

Dilanjutkan dengan tahap Interest, yaitu adanya partisipasi aktif siswa dalam berlangsungnya proses pembelajaran, guru membentuk kelompok belajar secara heterogen dengan tujuan agar proses pembelajaran lebih interaktif, heterogen maksudnya siswa yang memiliki kemampuan samahal itu didapat dari wawancara anatra peneliti dengan guru Mata Pelajaran matematika disekolah. Masing-masing kelompok terdiri atas 5 orang siswa, kemudian peneliti menjelaskan aturan dalam diskusi secara berkelompok.Setelah itu peneliti membagikan LKS untuk setiap kelompok dan peneliti juga memberikan arahan untuk mengerjakan LKS tersebut. Dibentuknya kelompok belajar ini agar dapat melatih kepercayaan diri siswa dalam mengemukakan pendapatnya masuk kepada tahapan Assurance, yaitu menanamkan kepercayaan pada diri siswa. Terlihat pada 


\section{JURNAL KIPRAH, Juli 2018; VII(1): 49-58 \\ e-ISSN: 2580-6947 \\ p-ISSN: 2354-7278}

Gambar 2 berikut ini bahwa siswa ikut berperan aktif dalam mengerjakan LKS yang telah dirancang oleh guru. LKS tersebut mampu membawa siswa kepada pemahaman mengenai materi himpunan yang berlangsung pada proses pembelajaran.

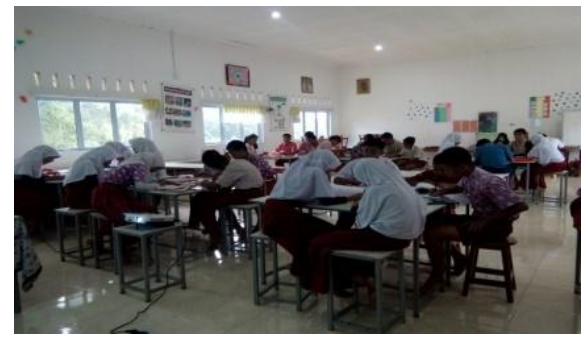

Gambar 2 Siswa mengerjakan LKS

Dalam penerapan model pembelajaran ARIAS berbantuan LKS di dalam kelas, proses pembelajaran lebih berfokus pada ketertarikan siswa dalam memahami materi, mengaitkan materi yang diajarkan dengan kehidupan seharihari, memberikan kepercayaan diri pada siswa, mengevaluasi hasil belajar yang telah dilaksanakan, serta mandapatkan kepuasan dalam bentuk penghargaan yang diberikan oleh guru. Guru berperan sebagai fasilitator dan motivator yang memberi dorongan/bantuan kepada siswa apabila menemukan kesulitan dalam mengerjakan LKS tersebut, dengan tidak mengarahkan siswa langsung kepada penyelesaiannya melainkan mengarahkan serta membimbing siswa dalam proses pengerjaan LKS. Selain itu, dalam proses pembelajaran dengan menerapkan model pembelajaran ARIAS ini, guru memberikan kesempatan kepada setiap kelompok untuk menyelesaikan permasalahan kontesktual tersebut. Proses pembelajaran kemudian dilanjutkan dengan meminta kepada perwakilan setiap kelompok untuk mempresentasikan hasil pengerjaan LKS. Guru kemudian memberikan kesempatan kepada setiap kelompok yang lain untuk bertanya maupun memberikan masukan dan saran terhadap selesaian yang dipresentasikan di depan kelas masuk ke dalam tahapan Assessment. Bagi siswa yang mampu mengemukakan pendapatnya diberikan penhargaan dalam bentuk lisan serta tambahan nilai berdasarkan tahapan Satisfaction. Hal ini bertujuan untuk mendorong siswa yang lain agar tidak takut dalam mengungkapkan pemikirannya. Pada akhirpembelajaran guru bersama-sama dengan siswa mengambil kesimpulan terhadap proses pembelajaran yang telah berlangsung, lalu guru menutup pembelajaran dengan ucapan terimakasih serta salam. Hal ini dapat terlihat pada Gambar 3, dimana siswa dengan percaya diri maju mempresentasikan hasil kerjaan kelompoknya.

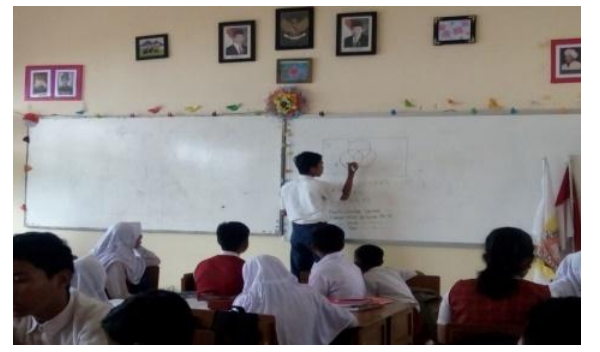

Gambar 3. Siswa mempresentasi hasil

Berdasarkan uraian diatas dapat disimpulkan bahwa siswa menerima informasi tentang pembelajaran yang telah dilaksanakan, menerima tentang kompetensi, memperhatikan dan mengamati penjelasan yang diberikan oleh guru, membaca petunjuk dan menyelesaikan permasalahan yang diberikan pada LKS, berdiskusi dengan teman, mempresentasikan penyelesaian, mendegar dan berpartisipasi aktif, serta meyimpulkan pembelajaran dan menerima apresiasi dari guru. Dari hasil observasi tersebut mengenai aktivitas guru dan aktivitas siswa selama proses pembelajaran dengan menggunakan model pembelajaran ARIAS sudah terlaksana dengan baik sesuai dengan rencana pelaksaan pembelajaran.

Hasil yang diperoleh dalam penelitian ini memiliki relevansi dengan hasil penelitian yang dilakukan oleh Dita Maulyta H, dkk (2017) di mana penelitian yang dilakukan merupakan Penelitian Tindakan Kelas (PTK), kesimpulan dari hasil tindakan penelitian menunjukkan adanya peningkatan kemampuan pemecahan masalah soal cerita pecahan dari pratindakan hingga siklus II.

Sementara ketuntasan belajar dapat 
dilihat berdasarkan pada tes akhir kemampuan pemecahan masalah siswa. Berikut adalah perolehan nilai siswa terhadap kemampuan pemecahan masalah, disajikan pada Tabel 5.

Tabel 5. Nilai Tes Kemampuan Pemecahan Masalah Siswa

\begin{tabular}{|c|c|c|c|}
\hline No & $\begin{array}{c}\text { Tingkat } \\
\text { Ketuntasan }\end{array}$ & $\begin{array}{c}\text { Banyak } \\
\text { Siswa }\end{array}$ & $\begin{array}{c}\text { Persentase } \\
\text { Jumlah } \\
\text { Siswa }\end{array}$ \\
\hline 1 & Tidak Tuntas & 8 & $20 \%$ \\
\hline 2 & Tuntas & 31 & $77,5 \%$ \\
\hline \multicolumn{2}{|c|}{ Jumlah } & 40 & $100 \%$ \\
\hline
\end{tabular}

Dan dapat dilihat krtiteria persentase aktivitas siswa (Qadriyah dalam Sinyo, 2015:352) dapat dilihat berdasarkan Tabel 6 berikut ini.

Tabel 6. Persentase Aktivitas Siswa

\begin{tabular}{|l|l|}
\hline $\begin{array}{c}\text { Persentase Aktivitas } \\
\text { Belajar Siswa }\end{array}$ & Taraf Keberhasilan \\
\hline $81-100$ & Baik sekali \\
$61-80$ & Baik \\
$41-60$ & Cukup \\
$21-40$ & Kurang \\
$0-20$ & Kurang sekali \\
\hline
\end{tabular}

Berdasarkan hasil tes akhir kemampuan pemecahan masalah, siswa yang memperoleh ketuntasan belajar $\geq 70$ sebanyak $80 \%$ dan masuk kedalam taraf keberhasilan baik.

\section{KESIMPULAN}

Berdasarkan hasil penelitian dan pembahasan dapat disimpulkan bahwa model pembelajaran ARIAS berbantuan LKS efektif dalam meningkatkan kemampuan pemecahan masalah matematis siswa. Oleh karena itu, guru dapat menerapakan model pembelajaran ARIAS ini pada pembelajaran matematika dalam meningkatkan kemampuan pemecahan masalah matematis siswa.

\section{Ucapan Terimakasih}

Terimakasih peneliti ucapkan kepada semua pihak yang berkontribusi terhadap penelitian ini, terutama pihak sekolah SMP N 7 Tanjungpinang Timur yang menjadi tempat pelaksanaan penelitian ini.

\section{REFERENSI}

Anjariyah, D dan Karlina, L. (2016). Pengaruh Model Pembelajaran ARIAS (Assrurance, Relevance, Interest, Assessment, and Satisfaction) Berbantuan Media Lingkungan terhadap Minat dan Hasil Belajar Matematika Siswa SMP pada Materi Aritmatika Sosial. [Online]. Tersedia: https://publikasiilmiah.ums.ac.id/bitstrea m/handle/11617/6976/38_14_Makalah\% 20Rev\%20Deka\%20Anjariyah.pdf?sequ ence=1\&isAllowed=y [22 Juli 2018]

Ega, F. (2013). Studi Komparatif Kecepatan Temu Kembali Informasi di Depo Arsip Kota Koran Suara Merdeka antara Sistem Simpan Manual denganFoto Repro. [Online]. Tersedia: http://eprints.undip.ac.id/40650/ $\quad[14$ Februari 2018]

Ivana, P. S. W. (2016). Penerapan Model Pembelajaran ARIAS (Assurance, Relevance, Interest, Assessment, and Satisfaction) Di Tinjau dari Minat Belaajar dan Hasil Belajar Matematika Siswa Kelas VIIIB SMP Kanisius Muntilan pada Materi Kubus dan Balok. [Online].

Tersedia:

https://repository.usd.ac.id/6742/2/12141 4014_full.pdf [09 April 2018]

Hidayati, N. (2018). Pengaruh Model Pembelajaran ARIAS (Assrurance, Relevance, Interest, Assessment, and Satisfaction) untuk Meningkatkan Hasil Belajar Mata Pelajaran IPS Materi Ekonomi Masyarakat Indonesia Siswa Kelas V di MINU WARU II Sidoarjo Tahun Pelajaran 2017/2019. Skripsi pada Universitas Negeri Sunan Ampel Surabaya: Tidak diterbitkan. 
JURNAL KIPRAH, Juli 2018; VII(1): 49-58

e-ISSN: 2580-6947

p-ISSN: 2354-7278

Yudiana, N. I. (2015). Peningkatan Kemampuan

Berpikir Kritis Melalui Penerapan Model Pembelajaran Deep Dilogue Critical Thinking dalam Pembelajaran Ekonomi pada Siswa Kelas. Diambil dari https://eprints.uny.ac.id/23828/1/SKRIP SI.pdf (21 Juli 2019)

Selisawati, P. (2016). Pengaruh Model Pembelajaran ARIAS (Assrurance, Relevance, Interest, Assessment, and Satisfaction) ditinjau dari Minat Belajar dan Hasil Belajar Matematika Siswa Kelas VIIIB SMP Kanisius Muntilab pada Materi Kubus dan Balok. [Online]. Tersedia:

https://repository.usd.ac.id/6742/2/12141 4014 full.pdf [22 Februari 2018]

Riduwan. (2011). Skala Pengukuran Variabel-Variabel Penelitian. Bandung: Alfabeta.

Sugiyono. (2018). Metode Penelitian Kuantitatif, Kualiatif, dan $R \& D$. Bandung. Alfabeta.

Supriyanti. (2015). Keefektifan Model Pembelajaran ARIAS Berbasis Etnomatematika terhadap Kemampuan Pemecahan Masalah Siswa Kelas VII. [Online]. Tersedia: http://lib.unnes.ac.id/21299/1/410141100 7-S.pdf [26 April 2018]

Yumima, S. (2015). Bagaimana Hasil Belajar Siswa SMP Negeri 5 Tidore Kepulauan Setelah Menapkan Model Pembelajaran Kooperatif Tipe Number Head Together. [Online]. Tersedia: https://media.neliti.com/media/publicatio ns/89778-ID-bagaimana-hasil-belajarsiswa-smp-negeri.pdf [06 Februari 2018] 